UDC

https://doi.org/10.33296/2707-0255-11(21)-06

BRATSLAVSKA ALLA

Senior Teacher, Aviation

English Department,

Ivan KozhedubKharkiv National Air

Force University

Kharkiv, Ukraine

https://orcid.org/0000-0003-1190-6759

\title{
FORMATION OFFUTURE PILOTS' ADAPTIVE COMPETENCE IN THE PROCESS OF THEIR PROFESSIONAL TRAINING: CHARACTERISTICS OF BASIC CONCEPTS
}

\begin{abstract}
The study of the formation of adaptive competence of future pilots in the training process is relevant given the active integration of Ukrainian aviation into the world community, development of relations and increasing interoperability of Ukrainian military aviation with the NATO Air Forces, in accordance with the Military Doctrine of Ukraine and the Strategic defense bulletin, as well as the urgent need to use the rules of the International Civil Aviation Organization (ICAO), the International Air Transport Association (IATA) and the European Aviation Safety Agency (EASA), which cooperate with ICAO, when using the common airspace. Recently, civil and military aviation have been working closely together, and military pilots are increasingly involved in evacuating the population during emergencies abroad, multinational military exercises, etc.

Pilots of civil and military aviation of Ukraine should adapt to the requirements of the new environment as soon as possible, and higher education institutions that train pilots should adjust the training process in accordance with the new requirements. The issue of adaptive competence in general and in particular, the adaptive competence of future pilots has not been sufficiently studied yet in the modern scientific literature and therefore needs further consideration. The article aims to define and characterize the basic concepts of formation of adaptive competence of future pilots in the process of their training, which will be followed by scientific substantiation, creation of structural-functional model of formation of adaptive competence of future pilots, and creation and approbation of author's technology at the educational institutions which train pilots.

The article considers and investigates the concepts of adaptation and its types; professional adaptation of the pilot; adaptability; competencies and competency; professional competency of the future pilot, its components and criteria of its formation; concepts and features of adaptive competency of future pilots. It also
\end{abstract}


describes and characterizes the features of the future activities of pilots and certain requirements for the training of pilots in civil and military aviation.

Key words: adaptation, adaptability, competence, adaptive competence, professional training.

Introduction. Recently, the problem of fruitful cooperation of Ukrainian pilots with foreign colleagues in the common airspace has become very important. The number of flights to other countries, both military and civil aviation, is growing, as is the number of joint military aviation exercises together with foreign air forces.

Forinstance, according to the training plan of the Armed Forces of Ukrainein 2020, thestrategic command post exercise "Joint Efforts - 2020" washeld on September 22-25, which was attended by about 12 thousand servicemen and 700 weapons and military equipment.

The event involved military units of the Armed Forces of NATO member states (USA, UK) for joint training and combat missions, advisers to the NATO Mission in Ukraine, representatives of the NATO Liaison Office in Ukraine, as well as instructors, military advisers, observers from the US, Great Britain, Germany, the Republic of Lithuania and the Republic of Poland.

According to the statements of the Strategic Defense Bulletin of Ukraine -2016, which aims to ensure the practical implementation of the Military Doctrine of Ukraine and the Concept of Development of the Security and Defense Sector of Ukraine and defines strategic and operational goals of defense reform, one of the main tasks is to bring the Armed Forces of Ukraine to NATO standards. This means that Ukrainian military pilots must meet certain requirements necessary to ensure interoperability with NATO troops, in particular, in the English language proficiency, pilots must receive level 2 according to the language standardization STANAG 6001 and level 4 according to the language scale of the International Civil Aviation Organization (ICAO).

While interacting with foreign military and civil aviation, pilots also need to be able to constantly adapt to various professional tasks, so adaptive competence is a 
professionally important quality of the future pilot and is part of their professional competence.

The article will consider the concepts of "adaptability", "adaptive competence", "professional training" of a pilot.

Initial Preconditions. Problems of adaptability, competence, as well as professional training of pilots and servicemen are given a lot of attention in modern pedagogy. In particular, such scientists as G. Yelnikova, V. Kirichenko, Y. Buntura, O. Kanishcheva, M. Vovk, I. Lyutenko, O. Ogienko, A. Pershina, V. Pishvanova, V. Yagupov, O. Kernytsky, T Rogova, V. Rogova and others study psychological training in their works. R. Makarov, O. Moskalenko, O. Brodova, R. Nevzorov dedicate their work to the study of pilot training. At the same time, the issue of adaptive competence of future pilots is currently insufficiently considered and needs further study.

Formulating goals of the article. The aim of the article is to define and consider the basic concepts of formation of adaptive competence of future pilots in the process of professional training for further research, scientific substantiation, creation of structural-functional model of formation of adaptive competence of future pilots and author's technology of implementation of this model in higher education institutions.

The statement of basic materials. First, consider the concept of "adaptation", from which the concept of "adaptability" is derived. "Adaptation, adaptation, habituation" means the action or process of changing something or change to meet a new goal or situation "[2, p. 1]. This term is also often understood as the process of acquiring such changes during the ontogenesis of a living organism or evolutionary development, which is sometimes called adaptation ogenesis in the Ukrainian scientific literature.

During life, a person has to adapt to different situations and play many different roles. The scientific literature defines several types of classifications of 
these roles. For example, according to the spheres of activity, the roles are divided into professional, family, etc. According to the level of the previous task, the roles are divided into conventional, i.e. fixed in the social structure, and interpersonal. According to the level of activity of the individual, the roles can be divided into ascriptive, or those that are set by a person's social position, and achievable, i.e. those that a person has achieved in the process of life.

Accordingly, adaptation can be considered in many aspects, such as psychological, social and professional adaptation. O. Lavrenko in his works provides the following definition of psychological adaptation: "Psychological adaptation is the aggregate properties of the individual, which characterize its resistance to environmental conditions and the level of adaptation to them; the result of such adaptation "[13, p. 1].

V. Volovych describes social adaptation as "adaptation of a person or social group to the social environment" [13, p. 1]. While N. Nychkalo characterizes the concept of "professional adaptation" in terms of interaction of people of different generations, their adaptation to independent work.

Regarding the success of professional adaptation, according to V. Kirichenko, the main criterion used to assess the success of this process is the development of a set of personality traits that minimize mental and physiological costs to achieve a certain result. "According to the life tasks facing the subject of work in each case, the content of the initial professional adaptation may reflect the socio-psychological (therefore in this period the most intensively developing abilities that help to adapt to the workforce), individual psychological component of this process (personal qualities that are the basis of the activity component of the profession will develop), etc. "[9, p. 1].

As for the professional adaptation of pilots, we can determine that it is a conscious process of acceptance by a personality of a pilot the content of professional activity. The process of adaptation of a pilot will include two components: namely 
professional adaptation and socio-psychological adaptation. O. Brodova notes that "adaptation of future pilots consists of the actual professional adaptation associated with flight activities and socio-psychological adaptation associated with the attitude of a pilot to employees of the aviation company, crew, management" [3, p. 4]. This will necessarily include a set of knowledge, skills and abilities acquired by a pilot in a higher education institution, namely, piloting skills of certain aircraft, skills of interaction with the crew (in the case of military pilots, as well as purely military skills), the acquisition of which will minimize mental and physiological costs for the successful performance of their professional duties.

Let us turn to the concept of "adaptability", which was considered by various scientists. For example, O. Kuznetsova believes that "adaptability is a stable property of the individual, which characterizes their ability to internal (intra-personal) and external (behavioral) transformations, restructuring, aimed at maintaining or restoring the balanced relationship of the individual with the micro- and macro-social environment. changes in its characteristics "[11, p. 22]. The scientist also characterizes the functions of adaptability, namely, the general function of adaptability. It is to ensure the achievement of a balanced relationship between the individual and the environment in unstable conditions based on internal and behavioral changes. This definition, in our opinion, fully reveals the essence of the concept of "adaptability".

As we can see, adaptability is closely related to human activity and development. As G. Yelnikov notes, "activity, as the basis of development, is always directed by three forces: external requirements, own motive and existing circumstances. The most productive activity is one that is self-motivated. Therefore, it is necessary to reconcile one's own motive with external requirements and take into account the existing situation. This will ensure the reality of actions and make them useful, both for a person who has internal requirements, and for society, the state, making external requirements to it "[6, p. 9]. 
Social and professional roles to which a person adapts in the process of their activities develop different types of personal competence. In most sources, competence refers to a dynamic combination or system of knowledge, skills, abilities, ways of thinking, views, values, and other personal qualities that determine a person's ability to solve certain problems, successfully socialize, and pursue professional activities.

According to the Dictionary of Modern English, "competency" consists of a person's abilities and skills to perform the necessary activities, possession of a special field of knowledge, and special skills required to perform certain professional duties. The concept of "competence" (from the Latin "competens" (appropriate, appropriate)) means a set of necessary for effective professional activity, systematic functional knowledge and skills.

Note that the concept of "competency" is significantly different from the concept of "competence". M. Golovan provides an analysis of the concepts of "competency" and "competence" and concludes that "competence - some alienated, predetermined requirement for training a person (properties or qualities, potential abilities of the person), competency - is the possession of competence, which is manifested in effective activities and includes personal attitude to the subject and product of the activity; competency is an integrative formation of personality that integrates knowledge, skills, abilities, experience and personal qualities that determine the desire, ability and willingness to solve problems and tasks that arise in real life situations, while realizing the importance of the subject and result, activity, "competence" is a systemic concept that has its own structure, levels, functions, unique characteristics, properties "[4, p. 12-13]. For example, the main competences of a pilot as defined by ICAO are:

- Communicationskills,

- Controloftheflightpathofaircraft - manualcontrol,

- Controloftheflightpathofaircraft - automaticcontrol, 
- Leadershipandteamwork

- Problemsolvinganddecisionmaking,

- Applicationofprocedures (procedure),

- Workloadmanagement

- Situationalawareness [1, p. 8].

I. Kubenko also emphasizes that competence should be distinguished from human qualifications. In contrast to the term "qualification", competence includes not only purely professional knowledge and skills, but also such qualities as initiative, ability to cooperate, work in a group, ability to assess the situation, think logically, extract, select and analyze information. More precisely, a person can become competent only after gaining adequate information, knowledge and practical experience. That is, in the formation of a competent personality, education plays a major role "[10, p.11].

In our work we will consider the adaptive competency of pilots as a systemic concept and integrative formation of personality, possession of competences necessary for their effective professional activity.

Consider the professional competency of the future military pilot, which, according to R. Nevzorov, is a complex system formation, "the main elements of which are the subsystem of professional knowledge, as logical system information recorded in the mind; subsystem of professional skills as mental formations, which consist in the assimilation of human ways and techniques of professional activity; subsystem of professional skills - actions that are formed in the process of repeating certain operations and brought to automatism; subsystem of moral and value positions, as a set of formed attitudes and orientations, attitudes and assessments of internal and environmental experience, reality, which determine the nature of professional activity and behavior of the specialist; subsystem of individual psychological characteristics of the specialist - a combination of different structural and functional components of the psyche, which determine the individuality, style of 
professional activity, behavior and are manifested in the professional qualities of the individual, which determine the need for constant self-development, creativity and self-improvement "[16, p. 108-109].

That is, future pilots must master a set of general scientific, general aviation and special knowledge, skills, moral, volitional, physical and psychophysiological qualities that will ensure their successful performance of tasks typical of their profession, and provide the prospect of continuous self-improvement and selfeducation. In his works, V. Nevzorov also identifies four criteria, "which make it possible to assess the formation of professional competence of the future military pilot in the process of air-tactical training" [15, p. 5]. These criteria include: cognitive component - intellectual criterion; praxeological component - practice-oriented criterion; motivational component - behavioral criterion; personal component - an individual criterion.

It should be borne in mind that the profession of a pilot is characterized by constant risk and a certain emotional tension. The actions of the pilot in combat flight are performed in the conditions of fleeting working situations, and this requires the rapid execution of complex intellectual actions. In civil aviation, the pilot also feels a great deal of responsibility for the passengers on board the aircraft. In addition, the need to speak English, which according to ICAO requirements is used as the main language of radio communication, is urgent when performing international flights. It should be noted that the ability to communicate in a foreign language is included in the list of higher education standards in the specialty "Military Administration" (by type of armed forces) according to Article 10 of the Law of Ukraine on Higher Education [7, p. 1]. That is, in the process of their professional activity, the pilot must very quickly adapt to changing situations, adequately and timely respond to them, apply all their acquired competencies to perform tasks successfully. Thus, the professional competence of the pilot will include a subsystem of professional knowledge, professional skills and mental formations, skills and abilities (including 
English language proficiency), brought to automatism, a subsystem of moral and value positions, individual psychological characteristics of the pilot that determine individuality, style of their professional activity.

Now let us turn to the concept of "adaptive competence", which can be defined as the ability to quickly adapt to changes in the social environment, the requirements and nature of its orders. According to the above statements, the adaptive competence of the pilot will be part of their professional competence and will consist of a system of their professional knowledge, skills and abilities, as well as his moral and value positions and individual psychological characteristics of the specialist, which will allow them to effectively adapt to flight, make the right decision to adequately respond to changes in the environment. The levels of adaptive competence of pilots can also be determined by intellectual, practice-oriented, behavioral and individual criteria that reflect the possibility of effective adaptation to professional situations, applying the acquired theoretical knowledge, automated skills and abilities of both piloting of aircraft, psychological and speaking abilities. The adaptive competence of future pilots should thus be one of the tasks of their professional training in higher education institutions.

Now consider the concept of "pilot training". In general, professional training is defined as obtaining a qualification in the relevant field. It is a purposeful process of teaching students / cadets professional knowledge and skills in order to acquire the skills needed to perform certain types of work. T. Rogova singles out several approaches of researchers to determine the essence of the quality of training, namely: "emphasis on the quality of educational content, educational standards, curricula and textbooks; focusing on the problem of the quality of the organization of the educational process, the quality of its scientific and methodological, informational, personnel, logistical, financial support; consideration of the quality of professional training from the standpoint of management, the process of ensuring, determining the 
mechanisms and factors for improving the quality of education in higher education institutions "[17, p. 301].

Speaking of the training of pilots, O. Moskalenko proposes to consider the training of aviation specialists as an integrative system of interdisciplinary knowledge, skills and abilities provided by the use of a comprehensive set of ground and flight training to solve practical problems of professional activity that allow for optimal interaction of teacher and cadets, regulated by ICAO international aviation standards and aimed at achieving a guaranteed pedagogical result [14, p. 251].

R. Makarov considers professional training of pilots as an integrative pedagogical process that contributes to the formation of psychophysiological qualities, resistance to extreme factors of professional activity and the achievement of a high level of efficiency of civil aviation pilots. O. Kernytsky defines the professional training of military pilots as follows: "it is a set of organizational structures, management measures, specific procedural principles, content, methods, organizational forms and various means of forming psychological readiness and professionally significant qualities of military pilots, methods and criteria for assessing their personal, professional and psychological readiness for flying in the army "[8, p. 10].

Thus, we see that the training of pilots should take into account the specifics of the future activities of the pilot, regulated by international aviation standards of ICAO and NATO (for military pilots), as well it should be aimed at developing professional competence of pilots, one of which is adaptive competence.

We would like to add that in formation of professional competency of future pilots must also take into account their individual characteristics, for which adaptive training is used. The adaptive system of education arose on the basis of the analysis of tendencies of improvement of educational process under the influence of the newest psychological and pedagogical theories for optimum achievement of the educational purposes bearing in mind individual features of students. 
As G. Yelnikova notes, that "adaptive learning has emerged as a necessary condition for the formation of an active, enterprising personality who lives and operates in unstable market conditions. The essence of adaptive learning is the organization of the educational process, which allows to actively master the educational information of each student, regardless of their individual characteristics, natural abilities, level of academic success, etc. "[5, p. 4].

"Adaptive means include the use of computer equipment and gadgets to search for information and establish feedback in self-control of the level and quality of learning information" [5, p. 7]. At the Kharkiv National Air Force University, the Department of Aviation English has developed a large number of tasks based on the Moodle resource, both tests and those that promote the development of communication skills, provide new educational information and teach research skills.

Conclusions. Directions for further investigation.Performing professional duties, a pilot must adapt very quickly to the changing situation, responding adequately and in a timely manner. This, in turn, requires the use of adaptive competence of a pilot, which includes a system of professional knowledge, professional skills, as well as moral and value positions and individual psychological characteristics of a specialist. Adaptive competence of future pilots is one of the tasks of professional training in relevant higher education institutions. In the further research the scientific substantiation, creation of structural and functional model of formation of adaptive competence of future pilots and author's technology of realization of this model in the higher educational institutions preparing pilots will be considered. 


\section{REFERENCES}

1. 8 CoreCompetenciesforFlightCrew - ICAO https://www.icao.int > safety > Documents.

Режимдоступу: https://www.icao.int/safety/TrainairPlus_Archive/Documents/South \%20Africa\%20Regional\%20Symposium\%20Presentations/Panel\%201\%20$\%$ 20Challenges/4\%20NGAP_\%20IATA\%20Presentation\%20VF.pdfю (датазвернення: 15.05.2021)
2. Oxford
Learner's
Dictionaries.

Режимдоступу: https://www.oxfordlearnersdictionaries.com/definition/english/adapt ive. (дата звернення: 25.05.2021)

3. Бродова О. Особливості професійної адаптації майбутніх пілотів вищих льотних навчальних закладів як об'єкт наукового дослідження. -Режим доступу: //

http://webcache.googleusercontent.com/search?q=cache:BRH22QDGYzkJ:jrnl.nau.e du.ua/index.php/VisnikPP/article/download/12386/16719+\&cd=2\&hl=ru\&ct=clnk\&g l=ua (датазвернення: 15.05.2021)

4. Головань М.С. Компетенція і компетентність: досвід теорії, теорія досвіду / М.С.Головань // Вища освіта України. - 2008. - № 3. - С. 23-30.

5. Сльникова Г.В. Деякі питання організації адаптивного навчання в закладах освіти // Електронне наукове фахове видання «Адаптивне управління: теорія і практика, серія «Педагогіка», випуск 10 (19), 2020.

6. Сльникова Г.В.Технологія адаптивного управління персоналом організації / // Науковий вісник Інституту професійно-технічної освіти НАПН України. Професійна педагогіка. - 2011. - № 1. - С. 8-14. - Режим доступу: http://nbuv.gov.ua/UJRN/Nvipto_2011_1_4 (дата звернення: 15.05.2021)

7. Закон України про вищу освіту (Відомості Верховної Ради (ВВР), 2014, № 37-38, ст.2004). - Режим доступу: https://zakon.rada.gov.ua/laws/show/155618/print (дата звернення: 10.05.2021)

8. Керницький, О. М. Методика формування психологічної готовності курсантів-льотчиків до льотної діяльності: Автореф. дис... канд. пед. наук: 13.00.02 / О.М. Керницький ; Укр. інж.-пед. акад. - Х., 2005. - 19 с.

9. Кириченко В.В. Професійна адаптація особистості: суб'єктноціннісний підхід до вивчення / Кириченко Віктор Васильович // Проблеми та перспективи розвитку практичної психології в Україні: матеріали II Всеукраїнської наукової Інтернет конференції, 24 жовтня 2013 р. / гол. ред. Гриньова Н.В. - Умань : Візаві, 2013. - С. 56- 57.

10. Кубенко. М Що таке компетентність і як іï розуміють в освіті // Додаток до електронного журналу «Теорія та методика управління освітою», Вип № 1, 2010 р. С. 1-7.

11. Кузнєцова О. В. Адаптивність, iї функції та характер співвідношення 3 інноваційністю // ScienceandEducationalNewDimension. PedagogyandPsychology, VI (72), Issue: 174, 2018 Sept. - Режим доступу:

(C) Українська інженерно-педагогічна академія

(C) ГО «Школа адаптивного управління соціально-педагогічними системами»

(C) Брацлавська А. 
https://seanewdim.com/uploads/3/4/5/1/34511564/httpsdoi.org10.31174send-pp2018174vi72-04.pdf (дата звернення: 15.05.2021)

12. Макаров, Р. Н., Рубец М. И., Неделько, С. Н., Бамбуркин, А. П. Авиационнаяпедагогика: учебник. Москва; Кировоград: МНАПЧАК: ГЛАУ.

13. Міхеєв О. М., Шульга М. О., Ничкало Н. Г. Адаптація // Енциклопедія Сучасної України: електронна версія [веб-сайт] / гол. редкол.: I.М. Дзюба, А.І. Жуковський, М.Г. Железняк та ін.; НАН України, НТШ. Київ: Інститут енциклопедичних досліджень НАН України, 2001. - Режим доступу: URL: http://esu.com.ua/search_articles.php?id=42642 (дата звернення: 24.05.2021)

14. Москаленко, О. І. Визначення сутності професійної підготовки льотного складу. Педагогіка формування творчої особистості у вищій i загальноосвітній школах, Випуск № 28, С. 250-255.

15. Невзоров Р.В. Компонентний склад фахової компетентності майбутніх військових пілотів та модель ії формування // Вісник Національної академії Державної прикордонної служби України, 2019, Випуск 2. С. 1-15.

16. Невзоров Р.В. Фахова компетентність майбутніх військових пілотів // Вісник Черкаського університету. Серія «Педагогічні науки». Випуск № 2.2019. - C. 104-109.

17. Рогова Т.В. Професійна підготовка студентів у ВНЗ: ознаки та якість// Збірник наукових праць «Педагогіка та психологія» - Харків. 2017. - Вип. 56. C. 294-301.

18. Розов В. И. Психология экстремальных ситуаций: адаптивность к стрессу и психологическое обеспечение: научно-практическое пособие / В. И. Розов. - К. : КНТ; Саммит-Книга, 2012. - 480 с.

\section{References}

1. 8 CoreCompetenciesforFlightCrew - ICAO https://www.icao.int > safety $>$ Documents.

Режимдоступу: https://www.icao.int/safety/TrainairPlus_Archive/Documents/So uth\%20Africa\%20Regional\%20Symposium\%20Presentations/Panel\%201\%20\%20Challenges/4\%20NGAP_\%20IATA\%20Presentation\%20VF.pdfю (датазвернення: 15.05.2021)
2. Oxford
Learner's
Dictionaries.

Режимдоступу: https://www.oxfordlearnersdictionaries.com/definition/english/ad aptive. (датазвернення: 25.05.2021)

3. Brodova Osoblyvostiprofesiynoyiadaptatsiyimaybutnikhpilotivvyshchykhl'otnykhnavchal'n ykhzakladiv yak ob"yektnaukovohodoslidzhennya. - Rezhymdostupu: //

4. Holovan' M.S. Kompetentsiyaikompetentnist': dosvidteoriyi, teoriyadosvidu / M.S.Holovan' // VyshchaosvitaUkrayiny. - 2008. - № 3. - S. 2330 . 
5. Yel'nykova H.V. Deyakipytannyaorhanizatsiyiadaptyvnohonavchannya v zakladakhosvity // Elektronnenaukovefakhovevydannya «Adaptyvneupravlinnya: teoriyaipraktyka, seriya «Pedahohika», vypusk 10 (19), 2020.

6. Yel'nykovaH.V.Tekhnolohiyaadaptyvnohoupravlinnyapersonalomorha nizatsiyi / // NaukovyyvisnykInstytutuprofesiyno-tekhnichnoyiosvity NAPN Ukrayiny. Profesiynapedahohika. - 2011. - № 1. - S. 8-14. - Rezhymdostupu: http://nbuv.gov.ua/UJRN/Nvipto_2011_1_4 (data zvernennya: 15.05.2021)

7. ZakonUkrayiny pro vyshchuosvitu (VidomostiVerkhovnoyiRady (VVR), 2014, № 37-38, st.2004). - Rezhymdostupu: https://zakon.rada.gov.ua/laws/show/1556-18/print (data zvernennya: 10.05.2021)

8. Kernyts'kyy,

O. M. Metodykaformuvannyapsykholohichnoyihotovnostikursantiv-l'otchykiv do l'otnoyidiyal'nosti: Avtoref. dys... kand. ped. nauk: 13.00.02 / O.M. Kernyts'kyy ; Ukr. inzh.-ped. akad. - KH., 2005. - 19 s.

9. Kyrychenko V.V. Profesiynaadaptatsiyaosobystosti: sub"yektnotsinnisnyypidkhid do vyvchennya / Kyrychenko Viktor Vasyl'ovych // Problemy ta perspektyvyrozvytkupraktychnoyipsykholohiyi $\mathrm{v}$ Ukrayini: materialy II Vseukrayins'koyinaukovoyi Internet konferentsiyi, 24 zhovtnya 2013 r. / hol. red. Hryn'ova N.V. - Uman' :Vizavi, 2013. - S. 56- 57.

10. Kubenko. M Shcho take kompetentnist' i yak yiyirozumiyut' v osviti // Dodatok do elektronnohozhurnalu «Teoriya ta metodykaupravlinnyaosvitoyu», Vyp № 1, 2010 r. S. 1-7.

11. Kuznyetsova O. V. Adaptyvnist', yiyifunktsiyi ta kharakterspivvidnoshennya $\mathrm{z}$ innovatsiynistyu // Science and Educational New Dimension. Pedagogy and Psychology, VI (72), Issue: 174, 2018 Sept. Rezhymdostupu:

https://seanewdim.com/uploads/3/4/5/1/34511564/httpsdoi.org10.31174sendpp2018-174vi72-04.pdf (data zvernennya: 15.05.2021)

12. Makarov, R. N., Rubets M. Y., Nedel'ko, S. N., Bamburkyn, A. P. Avyatsyonnayapedahohyka: uchebnyk. Moskva; Kyrovohrad: MNAPCHAK: HLAU.

13. Mikheyev O. M., Shul'ha M. O., Nychkalo N. H. Adaptatsiya // EntsyklopediyaSuchasnoyiUkrayiny: elektronnaversiya [veb-sayt] / hol. redkol.: I.M. Dzyuba, A.I. Zhukovs'kyy, M.H. Zheleznyak ta in.; NAN Ukrayiny, NTSH. Kyyiv: Instytutentsyklopedychnykhdoslidzhen' NAN Ukrayiny, 2001. Rezhymdostupu: URL: http://esu.com.ua/search_articles.php?id=42642 (data zvernennya: 24.05.2021)

14. Moskalenko,

O.

Vyznachennyasutnostiprofesiynoyipidhotovkyl'otnohoskladu.

Pedahohikaformuvannyatvorchoyiosobystosti

vyshchiyizahal'noosvitniyshkolakh, Vypusk № 28, S. 250-255. 
15. Nevzorov

R.V.

Komponentnyyskladfakhovoyikompetentnostimaybutnikhviys'kovykhpilotiv ta model' $^{\prime}$ yiyiformuvannya

VisnykNatsional'noyiakademiyiDerzhavnoyiprykordonnoyisluzhbyUkrayiny, 2019, Vypusk 2. S. 1-15.

16. Nevzorov R.V. Fakhovakompetentnist' maybutnikhviys'kovykhpilotiv // VisnykCherkas'kohouniversytetu. Seriya «Pedahohichninauky». Vypusk № 2.2019. - S. 104-109.

17. Rohova T.V. Profesiynapidhotovkastudentiv u VNZ: oznaky ta yakist'// Zbirnyknaukovykh prats' «Pedahohika ta psykholohiya» - Kharkiv. 2017. - Vyp. 56. - S. 294-301.

18. Rozov V. Y. Psykholohyyaékstremal'nykhsytuatsyy: adaptyvnost' k stressu y psykholohycheskoeobespechenye: nauchno-praktycheskoeposobye / V. Y. Rozov. - K. : KNT; Sammyt-Knyha, 2012. - 480 s.

\section{БРАЦЛАВСЬКА АЛЛА}

старший викладач кафедриавіаційної англійської мовиХарківського національногоУніверситетуПовітряних Сил ім. І.Кожедуба

м. Харків, Україна

\section{ФОРМУВАННЯ АДАПТИВНОЇ КОМПЕТЕНТНОСТІ МАЙБУТНІХ ЛЬОТЧИКІВ У ПРОЦЕСІ ПРОФЕСІЙНОЇ ПЦГОТОВКИ:} ХАРАКТЕРИСТИКА БАЗОВИХ ПОНЯТЬ

Анотація. Формування адаптивної компетентності майбутніх льотчиків у процесі професійної підготовки $\epsilon$ актуальним з огляду на активну інтеграцію української авіації у світову спільноту, розвиток взаємозв'язків та підвищення рівня взаємосумісності військової авіації України з Військово-повітряними Силами країн НАТО, згідно до вимог Воєнної доктрини України i Стратегічного оборонного бюлетеня, a також нагальною потребою використання норм Міжнародної цивільної авіації (ICAO), Міжнародної асоціації повітряного транспорту (IATA) та Європейського агентства з безпеки польотів (EASA), які співпрацюють з IКАО, під час використання спільного повітряного простору. Останнім часом цивільна та військова авіація працюють у тісній співпраці. Військові льотчики все частіше залучаються до виконання задач евакуації населення під час екстремальних ситуацій за кордоном, багатонаціональних військових навчань, тощо. Льотчики цивільної та військової авіації України мають адаптуватися до вимог нового середовища, а 
вищі навчальні заклади, що готують пілотів- коригувати процес навчання відповідно до нових вимог. Питання адаптивної компетентності взагалі та зокрема адаптивної компетентності майбутніх льотчиків $\epsilon$ недостатньо дослідженим у сучасній науковій літературі і потребує подальшого розгляду. Стаття має на меті визначити та охарактеризувати основні поняття формування адаптивної компетентності майбутніх льотчиків у процесі їхньої підготовки, за яким буде слідувати наукове обгрунтування, створення структурнофункціональної моделі формування адаптивної компетентності майбутніх льотчиків, а також створення і апробація авторської технології реалізації цієї моделі у закладах вищої освіти, що готують пілотів. У статті розглядаються поняття адаптації взагалі; професійної адаптації пілота зокрема; адаптивності; компетенції та компетентності; професійної компетентності майбутнього пілота, ii складові та критерії iï сформованості; поняття та особливості адаптивної компетентності майбутніх льотчиків. Також описуються та характеризуються особливості майбутньої діяльності льотчиків та певні вимоги до професійної підготовки пілотів цивільної та військової авіації.

Ключові слова: адаптація, адаптивність, компетентність, адаптивна компетентність, професійна підготовка.

\author{
БРАЦЛАВСКАЯ АЛЛА \\ старший \\ преподавателькафедрыавиационногоан \\ глийскогоязыка \\ Харьковского национального \\ университета Воздушных Сил \\ им. И. Кожедуба \\ г. Харьков, Украина
}

\title{
ФОРМИРОВАНИЕ АДАПТИВНОЙ КОМПЕТЕНТНОСТИ БУДУЩИХ ЛЁТЧИКОВ В ПРОЦЕССЕ ПРОФЕССИОНАЛЬНОЙ ПОДГОТОВКИ: ХАРАКТЕРИСТИКА БАЗОВЫХ ПОНЯТИЙ
}

Анотация. Формированиеадаптивнойкомпетентности будущих летчиков в процессе профессиональной подготовки является актуальным, учитывая активную интеграцию украинской авиации в мировое сообщество, развитиевзаимосвязей повышениеуровнявзимосовместимостивоеннойавиацииУкраины с Военновоздушными силами НАТО, согласно требований Военной доктрины Украины и Стратегического оборонного бюллетеня, а такженасущнойнеобходимостьюиспользования Международнойорганизациигражданскойавиации (ИКАО), Международной 
ассоциации воздушного транспорта (IATA) и Европейского агентства по безопасности полетов (EASA), которые сотрудничают с ИКАО, при использовании общего воздушного пространства. В последнее время гражданская и военная авиация работают в тесном сотрудничестве, военные летчики все привлекаются к выполнению задач эвакуации населения во время экстремальных ситуаций за рубежом, многонациональных военных учений. Летчики гражданской и военной авиации Украины должны адаптироваться к требованиям новой среды, а заведения высшего образования, готовящие пилотов корректировать процесс обучения в соответствии с новыми требованиями. Вопрос адаптивной компетентности вообще и в частности, адаптивной компетентности будущих летчиков недостаточно исследован в современной научной литературе и требует дальнейшего рассмотрения. Статья имеет целью определить и охарактеризовать основные понятия формирования адаптивной компетентности будущих летчиков в процессе их подготовки. Этипонятия в дальнейшем будут научнообоснованы, создана структурнофункциональная модель формирования адаптивной компетентности будущих летчиков, а также создана и апробирована авторская технология реализации этой модели в учреждениях высшего образования, готовящих пилотов.

В статье рассматриваются понятия адаптации и ее виды; профессиональной адаптации пилота; адаптивности; компетенции и компетентности; профессиональной компетентности будущего пилота, еесоставляющие и критерии ее сформированности; понятие и особенности адаптивной омпетентности будущих летчиков. Также описываются и характеризуются особенности будущей деятельности летчиков и определенные требования к профессиональной подготовке пилотов гражданской и военной авиации.

Ключевые слова: адаптация, адаптивность, компетентность, адаптивная компетентность, профессиональная подготовка.

(c) Українська інженерно-педагогічна академія

(C) ГО «Школа адаптивного управління соціально-педагогічними системами»

(C) Брацлавська А. 